\title{
LB 膜中での光反店
}

\author{
松本 睦良 \\ 工業技術院 物質工学工業技術研究所 \\ （テ305-8565＼cjkstart茨城県つくば市東 1-1）
}

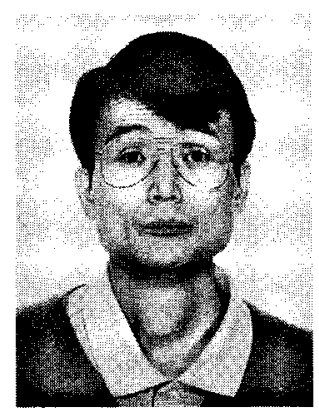

\section{Photoreactions in Langmuir-Blodgett Films}

\author{
Mutsuyoshi Matsumoto \\ National Institute of Materials and Chemical Research \\ (1-1 Higashi, Tsukuba-shi, Ibaraki-ken 305-8565)
}

\begin{abstract}
Photoreactions in Langmuir-Blodgett (LB) films were studied with special attention directed to structural changes of LB films accompanied by the photoreactions. First, a counter concept of free volume is presented. Three-dimensional cone-shaped structures were developed with trans-to-cis photoisomerization in polyion complex LB film of a water-soluble amphiphilic azobenzene. The structures alternately appeared and disappeared by illumination with UV and then visible light. The concept of free volume was found not to hold in the present case. Photoinduced J-aggregate formation of non-photochromic and photochromic dyes is discussed. Reversible photoisomerization of azobenzene in mixed LB films of azobenzene and dyes triggered irreversible J-aggregate dye formation. J-aggregate formation was accompanied by irreversible large morphological changes of the films. The photoisomerization of azobenzene served to induce self-organization of dye molecules. The photopolymerization of amphiphilic diacetylenes was investigated in LB films. This process was found to consist of blue-red, red, and yellow phases based on the spectral change. This change was found to depend on molecular orientation in the LB films. During the blue-to-red transition, the LB films showed considerable morphological change.

Key words : photoisomerization, LB films, azobenzene, photopolymerization, diacetylene
\end{abstract}

\section{1 はじめに}

両親媒性化合物は，水面上において親水性の部分を水 側，踈水性の部分を空気側に向けた配列を持つ単分子膜 を形成する。この単分子膜が水に不溶性の場合，固体基 板（ガラス板等）上に転写して得られる膜が LB 膜であ る”。LB膜は，水面上に単分子膜を形成してその単分 子膜を一層ずつ累積する過程を経由するため, 膜厚を分 子レベルで一定に制御できること，機能性の部分の配向 を制御できること，分子間の比較的弱い相互作用に基づ く自己組織化能を生かした構造の構築が可能になること 等の特徽を有している。

有機材料という観点からすると, LB 膜は単結晶と キャスト膜の中間に位置しているといえる。単結晶は分 子の配置がすべて決定されている。それに対して，LB 膜では膜の法線方向の配列はある程度そろっているが,
膜全体が単結晶のように分子配置が同一というわけでは ない。しかし,キャスト膜に比べると, 分子配列が制御 されている。また，多成分から成る単結晶の作製は必ず しも容易ではないが，キャスト膜の場合は自由度が大き い。LB膜はその中間であり，膜の構造が柔軟なために 他の成分との複合化が比較的容易である。また成形性か ら見ても，単結晶とキャス卜膜との中間に位置する。 LB 膜の最大の特街は, その二次元性である。分子配列 が制御されていることも併せて考えると, 膜の構造変化 が顥在化しやすいことになる。

本稿では，このような特徵を持つ LB 膜中での光反応 について述べるとともに, 光反応に伴う膜構造変化につ いても検討する。また，本稿での説明に使用した化合物 の構造式を Fig. 1 に示す。 

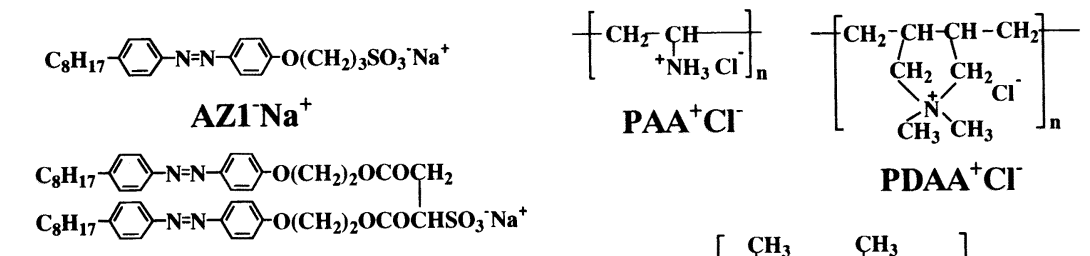

$\mathrm{PDAA}^{+} \mathrm{Cl}^{-}$
$\mathbf{P A A}^{+} \mathrm{Cl}^{-}$



CY

$\mathrm{AZ2}^{-} \mathrm{Na}^{+}$

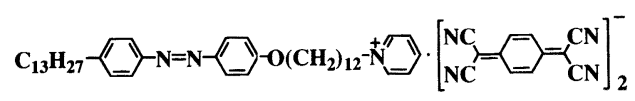

APT $\mathbf{m}=3: \mathbf{P I}(3-3)^{+} \mathrm{Br}^{-}$

$\mathrm{m}=$ 6: $\mathrm{PI}(6-6)^{+} \mathrm{Br}^{-}$

$\mathrm{ClO}_{4}$

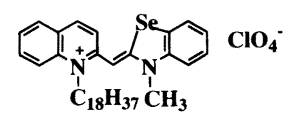

CY-Se

(1)

SP

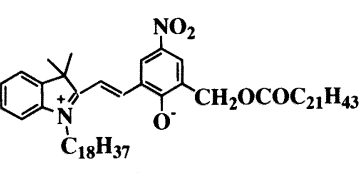

PMC

$$
\mathrm{CH}_{3}\left(\mathrm{CH}_{2}\right)_{\mathrm{m}-\mathrm{1}}-\mathrm{C} \equiv \mathrm{C}-\mathrm{C} \equiv \mathrm{C}-\left(\mathrm{CH}_{2}\right)_{\mathrm{n}} \mathrm{COOH}
$$

\section{DA(m-n)}

Fig. 1 Chemical Structures of the Molecules Used in This Study.

\section{LB 膜中での光異性化反応}

光異性化反応を示す典型的な分子はアゾベンゼンであ る。アゾベンゼンにはトランス体とシス体の 2 種類の異 性体が存在し, 熱力学的にはトランス体の方が安定であ る。紫外光照射によりトランス体からシス体への光異性 化反応が進行し，逆に可視光照射によりシス体からトラ ンス体への光異性化反応が進行する。光異性化反応に伴 い種々の物性が変化することが知られている。まずフォ トクロミズムとして知られる光吸収スペクトルの変化及 びコンフォメーションの変化, つまり分子の変形が起こ る。さらに, トランス体からシス体への光異性化反応に より分子断面積と双極子モーメントが増加する。LB膜 のように分子が密に充填されている系では，分子変形及 び分子断面積の増加は膜構造に大きな影響を与える。

LB 膜中での光反応に関する研究は 1970 年代から行 われているが，そのほとんどが光反応を利用する光記録 材料を構築する試みであった。最初に研究されたのはオ レフィンの光異性化反応であった ${ }^{2)}$ 。両親媒性チオイン ジゴ，スチルバゾールは LB 膜中でシス体からトランス 体への光異性化反応は進行したが，トランス体からシス 体の反応は進行しなかった。このことからトランス体か らシス体への異性化には「自由体積」が必要であると仮
定された。

LB 膜中での分子の占有面積を考えると, トランス体 では占有面積は比較的小さいのに対し, シス体では占有 面積が大きいと考えられる。分子が密に充填されている LB 膜中では占有面積が増大する方向の反応は進行しな いと仮定すると, トランス体からシス体への反応が進行 しない理由が説明できることになる。言い換えると, 膜 中に自由体積が存在すると, 光異性化に伴う分子占有(分 子断）面積の增加が吸収されることになる。この「自由 体積」の概念を用いて LB 膜中での光異性化反応が説明 されてきたが，この概念には次のような暗黙の仮定が 入っている。すなわち, 光異性化が進行しても, LB 膜 は二次元性を保持するということである。なお自由体積 の概念は単結晶中での光反応について発展したものであ り, LB 膜のような二次元系では自由面積といった方が よいのかもしれない。

この概念に基づき, アゾベンゼンが両親媒性シクロデ キストリンに包接された LB 膜を作製することにより， はじめてアゾベンゼンの可逆的な光異性化反応を確認す ることができた ${ }^{3)}$ 。たたア゙゙ベンゼン部分に比べて, 他 の部分の方がかさ高い場合も光異性化反応は進行するこ とが報告されている。この「自由体積」の概念に基づく と, 分子あたりの占有面積を制御することができれば光 
異性化反応を制御することが可能になることになる。実 質的な分子占有面積の制御にはポリイオンコンプレック ス法を用いるのが有効である。ポリイオンコンプレック ス法は, 両親媒性分子単独では良好な単分子膜を形成し なかったり, あるいは LB 膜としての累積がうまく行か ないときに用いられる方法として知られている4)。両親 媒性の分子が電荷をもっている場合, その反対荷電を持 つ水溶性のポリイオンを下相水に溶解しておくと, 水面 上の単分子膜にポリマーが吸着し, 安定な単分子膜を形 成するようになるとともに LB 膜としての累積も可能に なる。これはイオン交換反応とも考えられる。両親媒性 分子がプラスの電荷を持つ場合は水溶性のポリアニオン を, またマイナスの電荷を持つ場合は水溶性のポリカチ オンを用いることになる。

光異性化反応は生体中で重要な役割を担っている。視 覚に関連するロドプシンは，その情報処理にレチナール の光異性化反応を用いていることが知られており，その 原理は次のように考えられている。レチナールが光吸収 を行い遷移状態に昇った後，レチナールの光異性化反応 が数十 ps 以内で起こる。その後にレチナールを取り巻 くタンパク質が熱的にゆっくりと構造変化を行い, 最終 的には生理活性に結びついている。つまり,レチナール の光異性化に伴うコンフォメーション変化が, タンパク 質の構造変化のトリガーとなっている。この原理を利用 することにより, LB 膜の構造・機能制御が可能になる と思われる。

\section{$2 \cdot 1$ LB 膜中での光異性化反応の制御}

アゾベンゼンの分子占有面積制御による光異性化反応 の制御に関して述べる。アゾベンゼンを二個有するアニ オン性分子 $\mathrm{AZ}^{-} \mathrm{Na}^{+}$は純水上で単分子膜を形成する が，この単分子膜を固体基板上に累積することはできな かった。そこで水溶性のポリカチオン（4 種類）を溶解 した下相水上にこの分子を展開したところ，それぞれに 異なる表面圧一面積曲線が得られ, $\mathrm{PAA}^{+} \mathrm{Cl}^{-}, \mathrm{PI}(3-3)^{+}$ $\mathrm{Br}^{-}, \mathrm{PDAA}^{+} \mathrm{Cl}^{-}, \mathrm{PI}(6-6)^{+} \mathrm{Br}^{-}$の順に, 分子占有面積 が增大することが分かった。言い換えると同一のアゾべ ンゼン分子を用いているが，それぞれ異なる分子占有面 積を持つ LB 膜を作製することができたことになる。分 子占有面積が大きいことは, アゾベンゼンの自由体積が 大きいことに対応する。また，これらの LB 膜中ではア ゾベンゼンの可逆的な光異性化反応が進行した。紫外光 照射における光定常状態においてシス体のアゾベンゼン の分率を求め, LB 膜作製時の表面圧における分子占有 面積に対してプロットしたところ，アゾベンゼンの自由 体積が大きいほど, 光定常状態におけるシス体の分率が 高いことがわかった。この系においては自由体積の概念 が妥当であることを意味しているように思われる5)。こ のように, 分子の組み合わせによって生成するポリイオ
ンコンプレックスという超分子中のアゾベンゼン同士の 相対的な配置を制御することにより，アゾベンゼン由来 の膜機能を制御することができた。

$2 \cdot 2$ 光異性化反応による LB 膜の可逆的なモーフォ ロジー変化

水溶性のアゾベンゼン分子 $\mathrm{AZ}^{-} \mathrm{Na}^{+}$を用いて同様の 検討を行った。この分子は水溶性のため水面上で単分子 膜を形成しないが，やはりポリイオンコンプレックス法 を用いると LB 膜として累積することが可能であった。 つまり，この手法は水溶性の両親媒性分子に詨しても有 効であることがわかった。この LB 膜中でもアゾベンゼ ンの光異性化反応は可逆的に進行したが，興味深いこと にLB膜のモーフォロジーも可逆的に変化した。Fig. 2 に示すように, $\mathrm{AZ} \mathrm{1}^{-} / \mathrm{PDAA}^{+}$系において光照射前は膜 表面は滑らかであるが, 紫外光照射により膜表面から高 さ約 $5 \mathrm{~nm}$, 底面の径が約 $100 \mathrm{~nm}$ の円錐もしくは円柱形 の三次元構造体が形成された。この三次元構造体は可視 光照射によりほぼ消失した。この可逆的モーフォロジー 変化の機構は次のように考えられる。紫外光照射により トランス体からシス体への光異性化反応が進行すると分 子断面積が増加する。通常の系では, 平均の分子断面積 が分子占有面積に一致するまで異性化が進行し，そこで 反応が止まると考えられる。ところが，この系では，平 均の分子断面積が分子の占有面積を超えてもさらに光異 性化反応が進行したと考えられる。そして，断面積の超 過分を膜中に収容するために，膜構造が変化したものと 考えられる。この構造変化として一番考えやすいのが, 二次元の膜が部分的に湾曲することである。可視光照射 により分子占有面積が減少すると元の状態が復元する。 このような機構を仮定することにより現象を説明するこ とができる。重要なことは, 光異性化反応に伴い二次元 的な膜構造が大きな変化を示すことである。つまり自由 体積の概念はこの系に適用できないことがわかる6)。な お同様な現象が，アゾベンゼンをペンダントしたポリ マーLB膜についても報告されている7)。

\section{$2 \cdot 3$ 光異性化反応を利用した色素会合体制御}

LB 膜の構造・機能を光を用いて制御する試みとし て，アゾベンゼンの光異性化反応を利用した導電率のス イッチングに関して研究を行ってきた。用いた分子は APT である。この分子はアゾベンゼンと有機導電体で 知られる TCNQ 錯体を併せ持っており，アゾベンゼン の光異性化とともに LB 膜の横方向の導電率がスイッチ ングする $\left.{ }^{8)}, 9\right)$ 。興味深いことに, 導電率のみならず, TCNQの配向も可逆的に変化することがわかった。つ まり, 原理的にはロドプシンの場合と同じことになる。 この LB 膜は単一成分系であり，アゾベンゼンの光異性 化に伴い, 一種のシグナルが形成され，そのシグナルが 分子内の TCNQ 部分へ伝達されたと考えられる。多成 

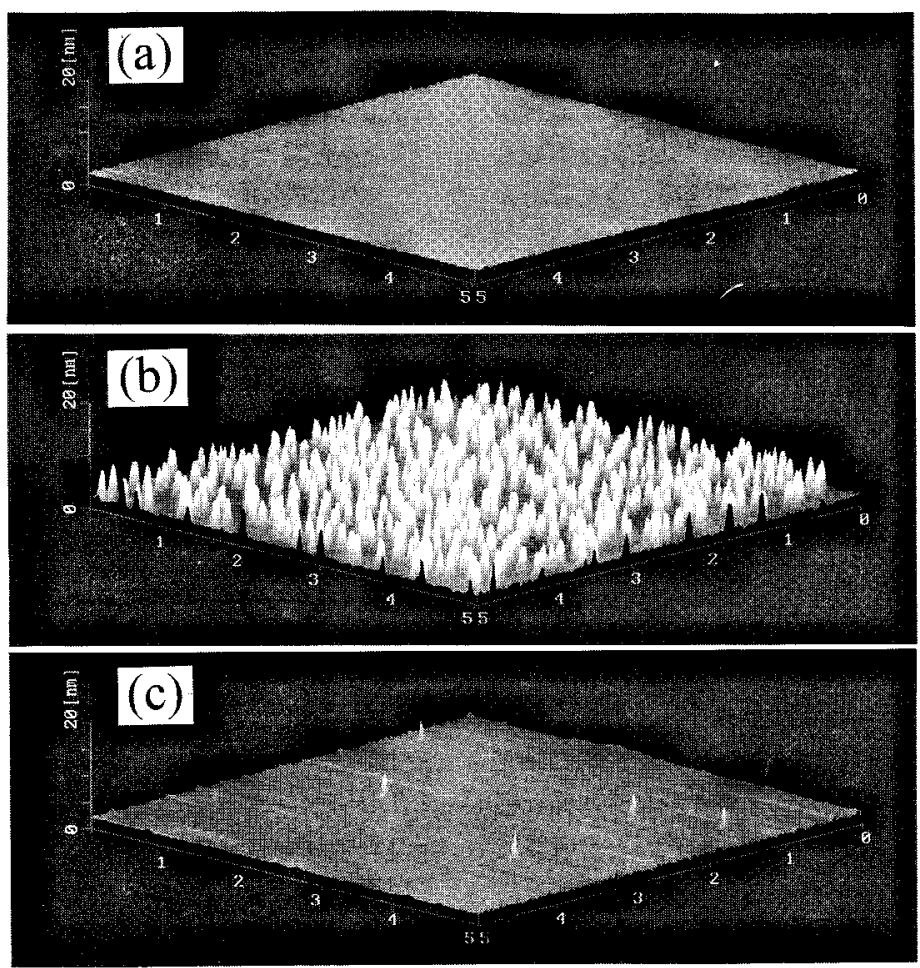

Fig. 2 AFM images $(5 \mu \mathrm{m} \times 5 \mu \mathrm{m})$ of a Single-layer LB Film of AZ1$/ \mathrm{PDAA}^{+}$before and after Illumination. (a) before illumination, (b) after illumination with UV light, (c) after illumination with visible light.

分系の LB 膜中では，この種の信号は分子間で伝達され ると期待される。

$2 \cdot 3 \cdot 1$ 非フォトクロミック分子との混合 LB 膜

$\mathrm{APT}$ 分子と両親媒性シアニン色素分子の混合 LB 膜 中での，アゾベンゼンの光異性化反応を利用したシアニ ン会合体の制御に関して研究を行った。アゾベンゼンと して TCNQを含む APTを用いたのは，TCNQ 部分が ないと LB 膜中で光異性化反応が進行しなかったからで ある。ここに示した 2 種類のシアニン分子 CY及び CY-Se はいずれも単一成分の LB 膜を作製するとJ 会 合体を形成しやすい分子である。ここで，クロモフォア が二次元的に煉瓦積みになったような分子配列（一次元 的な分子配列という説もある) の会合体をJ会合体と呼 ぶ。J会合体を形成すると, 吸収スペクトルは長波長シ フトし，かつ線幅が狭くなる。逆に吸収スペクトルが長 波長シフトすると J 会合体の形成を仅定する場合が多 い。光照射前は, $340 \mathrm{~nm}$ 付近のアゾベンゼンによる吸収, $500 \mathrm{~nm}$ 付近の CY ダイマーによる吸収, $530 \mathrm{~nm}$ 付近の $\mathrm{CY}$ モノマーによる吸収, $580 \mathrm{~nm}$ 付近の CY の J 会合体 による吸収がみられる。紫外光・可視光交互照射を行う とアゾベンゼンが可逆的に光異性化を行い, それととも
にJ吸収帯の増加と,ダイマー吸収帯の減少がみられた。 この結果は，アゾベンゼンの光異性化反応をトリガーと して，同一LB 膜中に共存する CY 分子の会合体形成が 促進されたことを示している。さらにこの過程を AFM を用いて検討してみた。Fig. 3に光照射前後の AFM 像を示す。光照射前は, 多少の欠陥はあるものの 膜は二次元的であったが, 光照射により」吸収帯が成長 した後には，LB膜の膜表面から底面の直径が $100 \mathrm{~nm}$, 高さが $10 \mathrm{~nm}$ の冈錐形の隆起物の成長が見られた。この 構造体は $\mathrm{J}$ 吸収帯とともに成長し, 最終的に底面の直徍 が $200 \mathrm{~nm}$, 高さが $30 \mathrm{~nm}$ の円錐形の隆起物がみられた。 このことは，この三次元の構造体が CY 分子で形成され ているを示唆する。全体の描像としては，アゾベンゼン の光異性化反応がトリガーとなり, CY 分子の自己組織 化過程を促進したものと思われる ${ }^{10)}$ 。このことはCY分 子が J 会合体を形成しやすいことからも明らかである。 その際に, $\mathrm{CY}$ 分子の一部が, 二次元構造よりも熱力学 的に安定な三次元構造をとるため，LB 膜表面からの円 錐形の隆起物を形成したものと思われる。なおこのよう な J 会合体形成及び膜のモーフォロジー変化は不可逆で あった。 


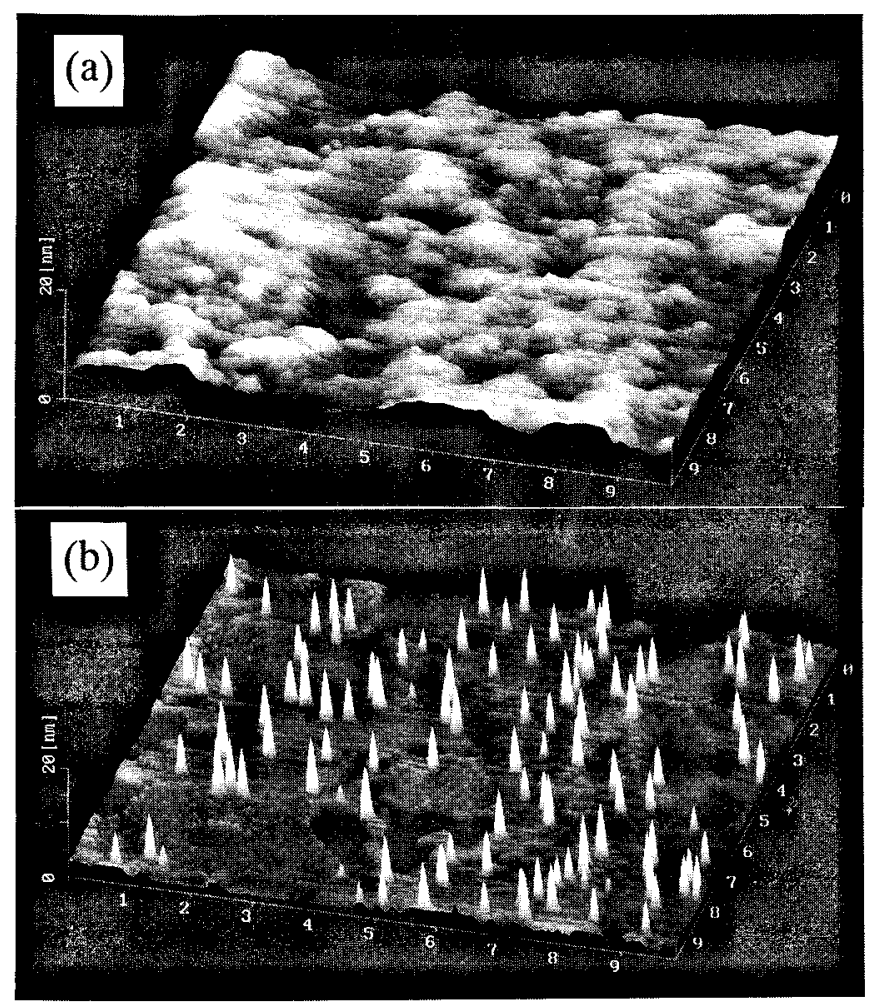

Fig. 3 AFM Images $(10 \mu \mathrm{m} \times 10 \mu \mathrm{m})$ of a Single-layer Mixed LB Film of CY and APT before and after Illumination Cycles.

(a) before illumination, (b) after illumination cycles.

上記の $\mathrm{J}$ 会合体形成が, CY/APT 系に特有な現象で あるのか，あるいは，もっと一般性を持った現象である のかを検討するために, CY-Se 分子を用いて同様の検 討を行ってみた ${ }^{11}$ 。 $\mathrm{CY}-\mathrm{Se}$ 分子も単一成分の LB 膜を 作製すると J 会合体を形成する。APT との混合 LB 膜 を作製すると光照射前はJ吸収帯がみられなかった。こ の混合 LB 膜に紫外光・可視光交互照射を行うと,アゾ ベンゼンはやはり可逆的に光異性化反応を示したが, $\mathrm{CY}-\mathrm{Se}$ 分子に基づく吸収に変化はみられなかった。と ころが，光照射後暗所下に保持すると， $\mathrm{J}$ 会合体に基づ く吸収が徐々に成長した。このJ会合体形成前後の LB 膜の AFM 像を観察すると，やはり J 会合体形成後は三 次元の構造体の成長がみられた。この系では円錐の数は $\mathrm{CY}$ 系に比べてかなり少ないが, そのかわりサイズは大 きく, 大きい円錐では底面の直径が $2000 \sim 3000 \mathrm{~nm}$, 高 さが 200 300 nmであった。いずれの系においても三次 元構造体がシアニン分子のみから生成していると仮定す ると, CY 系に比べて, CY-Se系では構造体一個あた りに存在する分子数は 3 桁大さいことになる。

三次元構造体の形成を結晶化過程とのアナロジーで考 えると, CY 采と CY-Se 系の違いを理解しやすい。勿
論 LB 膜中で観察されたこのような三次元構造体が単結 晶のような分子配列を持っていると主張しているわけで はない。三次元構造体の数が核生成に対応するとすると $\mathrm{CY}$ 系の方が核生成サイトの数が多いことになる。核生 成サイトの数の多い系ほど結晶の数は多く，その代わり に結晶のサイズは小さくなる。この考え方と観測結果は 定性的に矛盾しない。

\section{$2 \cdot 3 \cdot 2$ フォトクロミック分子との混合 LB 膜}

より複雑な系として，PMC と APT の混合 LB 膜に おける J 会合体形成についても検討してみた ${ }^{12}$ 。熱力学 的には PMCよりもその異性体である SPの方が安定で あるため，LB膜作製には SP 用いることになる。こ れまでに, SP と長鎖アルカンの混合 LB 膜を室温で紫 外光照射すると SP が PMC に異性化したが, $35^{\circ} \mathrm{C}$ 以 上の高温での光照射では SP が PMC に光異性化するだ けでなく，生成した PMCがJ会合体を形成することが 報告されている(1)。つまり，PMCは条件さえ整えばJ 会合体を形成しやすい化合物であると思われる。

SP と APT の混合 LB 膜をまず作製し，その後 334 $\mathrm{nm}$ の光照射を行ったところ, SP から PMCへの異性化 が観測された。この時に共存する APTもトランス体か 
らシス体へ異性化した。この後可視光，紫外光を交互照 射すると，やはり PMCの J 会合体が成長した。この J 会合体形成においては，非フォトクロミック分子の場合 と異なり, 光照射によりアゾベンゼンだけでなく色素分 子も異性化するため, その機構の詳細に関して不明な部 分も多い。アルカンとの混合 LB 膜では高温でのみ $\mathrm{J}$ 会 合体が形成したのに対して，アゾベンゼンとの混合 LB 膜ではこの過程が室温で進行したことから，アゾベンゼ ンの光異性化がトリガーとなり PMC の J 会合体形成を 誘起したと考えている。

この $\mathrm{J}$ 会合体形成に伴う膜のモルフォロジー（形態） 変化を検討するために AFM を用いてその場観察を行っ た。光照射前は，単分子膜の中に二分子膜の厚みを持つ 円形ドメインが埋め込まれた構造をしている。SPのモ ル分率を増やすと, 円形ドメインの面積分率が増加した ことから, 円形ドメインは SP がリッチな相であると思 われる。最初の $334 \mathrm{~nm}$ の光照射ではこの構造はほとん ど変化しなかったが, その後の可視光, 紫外光の交互照 射により，まずドメインの内部に盛り上がったような欠 陥が現れ，その後その部分を核として，徐々にデンドラ イト状の構造に変化していった。このような PMC の光 誘起 $\mathrm{J}$ 会合体形成及びモルフォロジー変化は, アルカン との混合 LB 膜を室温で光照射しても観測することはで きなかった。また, APT 単独系及び SP 単独系の LB 膜の光反応に扔いてもこのような大きなモルフォロジー 変化は起こらなかった。このことから，このモルフォロ ジー変化はPMC の J 会合体形成に密接に関連している と思われる。つまり, デンドライト状の構造に変化した 部分は，J会合体の形成した部分であると思われる。

\section{3 ジアセチレン LB 膜の光重合}

ジアセチレンは，固相状態において紫外光あるいは $\gamma$ 線の照射により，トポケミカルに重合することが知られ ている。単結晶に打いてはジアセチレン部分の分子配向 がある特定の範囲にある場合のみ重合が進行する。つま り, ジアセチレン部分が平行に配置していると考え, 分 子間距離が約 $0.5 \mathrm{~nm}$, 隣接する分子の中心を結ぶ直線 と分子とのなす角が約 $45^{\circ}$ の場合に重合が進行するとさ れている(14),15)。また，ポリジアセチレンは，温度上昇に より青相から赤相への相転移を起こすことが知られてい る。DA (12-8) のカドミウム塩の LB 膜においては, 光 照射により青相を形成した後, 加熱により青相から赤相 への転移が起こるだけでなく, 青相をさらに光照射して も青相から赤相への転移が起こるが，その機構の詳細は 知られていない(16).17)。

まず，分子長が等しく, ジアセチレン部分の位置の異 なる一連の両親媒性ジアセチレン分子 $\mathrm{DA}(\mathrm{m}-\mathrm{n})$ を合成 $(m+n=20,2 \leqq n \leqq 10)$ し，そのカドミゥム塩の LB
膜の重合特性を検討した ${ }^{18)}$ 。これらの分子の表面圧一面 積曲線はほほ等しく, 表面圧が $60 \mathrm{mN} / \mathrm{m}$ まで安定であっ た。また累積表面圧における分子占有面積から分子間距 離を計算すると $0.51 〜 0.52 \mathrm{~nm}$ となり, 重合可能な結晶 の場合とほぼ一致する。低圧水銀灯を用いてそれでれの LB 膜に紫外光を照射すると， 3 種類の重合挙動が観察 された。（i ）青一赤相と略称する場合について Fig. 4 に示す。この図は照射時間の変化に伴う DA (12-8) の力 ドミゥム塩の LB 膜の吸収スペクトル変化である。まず $640 \mathrm{~nm}$ と $590 \mathrm{~nm}$ に極大を持つ吸収帯が成長し, その後, $540 \mathrm{~nm}$ と $500 \mathrm{~nm}$ に極大を持つ吸収帯が成長するととも に，前者の吸収帯が消失する。 $\mathrm{n}=6,8,10$ が該当する。 （ii）最初から $540 \mathrm{~nm}$ の吸收帯が成長し，そのまま飽和 する。 $\mathrm{n}=4$ の場合に見られ，赤相と略称する。（iii） $600 \mathrm{~nm}$ 以下の吸収が全体に增加するが，極大を示さな い。 $\mathrm{n}=2$ の場合が該当し, 黄相と略称する。

このような重合の違いは, ジアセチレン部分の相対的 な配置の違いに起因すると思われる。そこで，LB 膜中 での分子配向について検討するために, 重合前の LB 膜 について，IR スペクトルの測定を行った。ジアセチレ ン部分の吸収は強度が小さいために, $\mathrm{CH}_{2}$ の対称及び 逆対称の伸縮振動について定量的な取り扱いを行った。 これらの吸収について，透過スペクトルと反射吸収スペ クトルでの強度を比較することでアルキル基の基板法線 からの平均傾き角を求めたところ, 青一赤相については 19 220, 赤相については $24 \sim 27^{\circ}$, 黄相については 18 ～ $20^{\circ}$ であった。さらにX 線回折法により一層あたりの 膜厚を求め，アルキル基，ジアセチレン部分のそれぞれ の長さを分子模型から見積もることにより，ジアセチレ ン部分の LB 膜中での傾き角を求めると，青一赤相につ

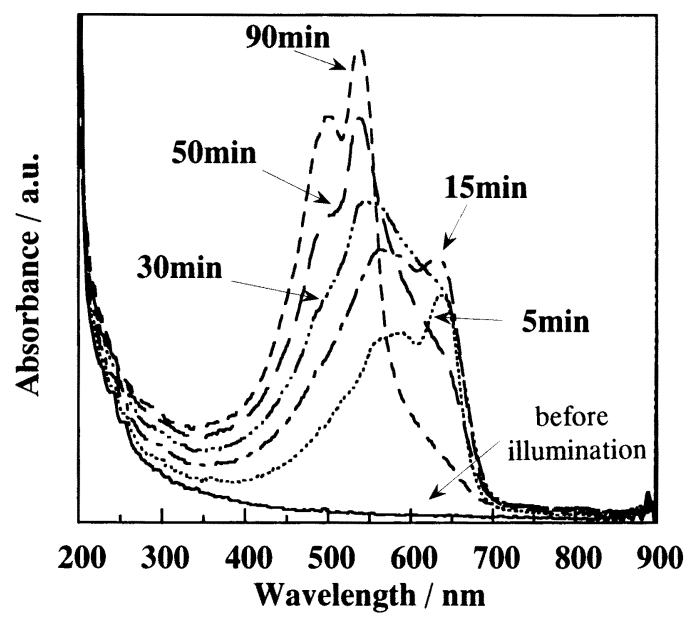

Fig. 4 Change in Absorption Spectrum of a Single-layer LB Film of Cadmium Salt of DA(12-8) on illumination with UV Light. 



Fig. 5 AFM Images ( $5 \mu \mathrm{m} \times 5 \mu \mathrm{m}$ ) of a Single-layer LB Film of Cadmium Salt of DA(12-8) on Illumination with UV Light. (a) before illumination, (b) after illumination for $15 \mathrm{~min}$, (c) after illumination for $90 \mathrm{~min}$.

いては約 $45^{\circ}$ であり，重合可能な結晶と同様の值が得ら れた。また赤相では青一赤相に比べてジアセチレン部分 の傾き角が大きく, 黄相では傾き角が小さいことが分 かった。黄相では1,4-付加ではなく，1,2-付加によっ て重合が進行している可能性もある。

さらに青一赤相の転移の機構について検討するため, Fig. 4 に示したスペクトルに対応する照射時間におい て，AFM を用いて膜表面のその場観察を行った ${ }^{19}$ 。代 表的な像を Fig. 5 に示す。光照射前は，平滑な面の上 に三次元構造が点在する構造を持っている。光重合によ り青相が形成される照射時間においては，モルフォロ ジーにほとんど変化は見られなかった。しかし，青相が 赤相に転移し始めると, 膜表面から, 細かい三次元の構 造が出現してきた。照射時間が 50 分以降は，モルフォ ロジーに顕著な変化は見ら机なかった。またIRスペク トルから，青相から赤相への転移において，ゴーシュ構 造を持つアルキル基の割合が増加することが分かった。

これらのことから次のようなスキームが考えられる。 （i）重合の初期段階で青相で存在する間は，トポケミ カルな反応と考えられる。これは, AFM 像, IR スペク トルにほとんど変化が見られないことから示唆される。 （ii）青相から赤相への転移においては, 次のような構 造変化が起こっていると思われる。重合の進行に伴い, ポリマー主鎖が長くなり，そのことが LB 膜構造にスト レスを与えると思われる。これは重合前の分子配列と重 合後の分子配列が完全には一致しないことに起因する。 このストレスがあるスレッシュホールドを越えると，ス トレスを緩和するために, 膜構造が変化する。この際に, ポリマー主鎖の有効共役長が減少するために吸収帯が短 波長側にシフトしたものと思われる。また,この膜構造 の変化がモルフォロジーの変化をももたらし, さらに， アルキル基の充填状態が乱れ，ゴーシュ構造を持つアル キル基の割合が増加したものと思われる。（iii）赤相に 転移してからは，膜に既にかなりの乱れが導入されてい
るため，モルフォロジーにもアルキル基の充填状態にも 顕著な変化は観測されなかった。

このように, 光重合の際に LB 膜の構造が大きく変化 する可能性があるので, LB 膜中で反応が起こる系を取 り扱う場合には注意が必要であることが分かる。

\section{4 結語}

LB 膜という場での光反応について述べてきた。トポ ケミカルと考えられている光反応も，場合によっては LB 膜の構造を大きく変化させることが分かった。LB 膜が柔軟であるため構造変化が起こったものであり，な おかつ LB 膜が二次元系であることから, その構造変化 を追跡することが容易になったと考えられる。このよう に柔軟に構造変化を起こすという意味では生体に近いと も言える。観点を変えると，LB膜中での反応を検討す る場合には，二次元から三次元への変化も念頭に置く必 要があることを示している。LB膜が柔軟であるという ことは膜構造が柔軟であることのみならず，分子設計も 柔軟に行えることを意味している。この柔軟性のために 他の材料との複合化も可能であり, 無機化合物との複合 化についても検討を行っているが20) 22), 紙数の関係で 省略する。このような特徴を有する LB 膜を利用した柔 軟な情報変換素子の構築が期待される。

(受付：2000年 5 月 11 日, 受理：2000年 6 月 16 日)

$$
\text { 文献 }
$$

1）福田清成, 加藤貞二, 中原弘雄, 柴崎芳夫, “超薄 分子組織膜の科学 単分子膜から LB 膜へ” 講談 社サイエンティフィック (1993).

2) D. G. Whitten, Angew. Chem. Int. Ed. Engl., 18, 440, (1979).

3) A. Yabe, Y. Kawabata, H. Niino, M. Matsumoto, A. Ouchi, H. Takahashi, S. Tamura, W. Tagaki, H. Nakahara, K. Fukuda, Thin Solid Films, 160, 33 
(1988).

4) M. Shimomura, T. Kunitake, Thin Solid Films, 132, 243 (1985).

5) H. Tachibana, R. Azumi, M. Tanaka, M. Matsumoto, S. Sako, H. Sakai, M. Abe, Y. Kondo, N. Yoshino, Thin Solid Films, 284-285, 73 (1996).

6) M. Matsumoto, D. Miyazaki, M. Tanaka, R. Azumi, E. Manda, Y. Kondo, N. Yoshino, H. Tachibana, J. Am. Chem. Soc., 120, 1479 (1998).

7) T. Seki, K. Tanaka, K. Ichimura, Macromolecules, 30, 6401 (1997).

8) H. Tachibana, T. Nakamura, M. Matsumoto, H. Komizu, E. Manda, H. Niino, A. Yabe, Y. Kawabata, J. Am. Chem. Soc., 111, 3080 (1989).

9) H. Tachibana, M. Matsumoto, Adv. Mater., 5, 796 (1993).

10) M. Matsumoto, H. Tachibana, F. Sato, S. Terrettaz, J. Phys. Chem. B, 101, 702 (1997).

11) H. Tachibana, F. Sato, S. Terrettaz, R. Azumi, T. Nakamura, H. Sakai, M. Abe, M. Matsumoto, Thin Solid Films, 327-329, 813 (1998).

12) S. Terrettaz, H. Tachibana, M. Matsumoto, Langmuir, 14, 7511 (1998).
13) E. Ando, J. Miyazaki, K. Morimoto, H. Nakahara, K. Fukuda, Thin Solid Films, 133, 21 (1985).

14) R. H. Baughmann, J. Polym. Sci., Polym. Phys. Ed., 12, 1511 (1974).

15) V. Enkelmann, Adv. Polym. Sci., 63, 91 (1984).

16) K. Kuriyama, H. Kikuchi, T. Kajiyama, Langmuir, 14, 1130 (1998).

17) A. Saito, Y. Urai, K. Itoh, Langmuir, 12, 3938 (1996).

18) H. Tachibana, Y. Yamanaka, H. Sakai, M. Abe, M. Matsumoto, Macromolecules, 32, 8306 (1999).

19) H. Tachibana, Y. Yamanaka, H. Sakai, M. Abe, M. Matsumoto, Langmuir, 16, 2975 (2000).

20) Y. Taguchi, R. Kimura, R. Azumi, H. Tachibana, N. Koshizaki, M. Shimomura, N. Momozawa, H. Sakai, M. Abe, M. Matsumoto, Langmuir, 14, 6550 (1998).

21) H. Tachibana, Y. Yamanaka, R. Kumai, A. Asamitsu, M. Matsumoto, Y. Tokura, Synth. Met., 102, 1485 (1999).

22) H. Tachibana, Y. Yamanaka, H. Sakai, M. Abe, M. Matsumoto, Chem. Mater., 12, 854 (2000). 


\section{[総説 $]$}

\section{LB 膜中での光反応}

松 本 睦 良

工業技術院 物質工学工業技術研究所

（テ305-8565＼cjkstart茨城県つくば市東 1-1）

LB 膜中での光反応について、それに伴う構造変化の観点から検討した。まず、自由体積の概念に対する反例 を提示した。水溶性両親媒性アゾベンゼンのポリイオン錯体 LB 膜において、トランスーシスの光異性化に伴い 三次元の円錐形の構造が膜表面から形成した。この構造体は、紫外光及び可視光での交互照射により可逆的に形 成した。この結果から、現在の系はそれまで受け入れられていた自由体積の概念が当てはまらないことが分かっ た。次に、非フォトクロミック及びフォトクロミック色素の光誘起 J会合体形成について述べた。アゾベンゼン と色素の混合 LB 膜中での可逆的な光異性化が、色素の不可逆的な J 会合体形成をもたらした。この J 会合体形 成に伴い、膜のモルフォロジーも不可逆的に大きく変化した。アゾベンゼンの光異性化は、色素分子の自己組織 化を誘起したと思われる。最後に、両親媒性ジアセチレン LB 膜の光重合について検討した。LB 膜中での光重 合は、スペクトル変化に基づいて、青一赤相、赤相、黄相に分類された。このような異なるスペクトル変化は、 LB 膜中での分子配向の違いに起因すると思われる。青一赤相の転移の間に、大きなモルフォロジー変化が観測 された。

（連絡者：松本睦良） Vol.49, No.10，1099（2000）

\section{[総説］＼cjkstart高機能ベシクルの高次構造}

一非イオン性両親媒性化合物によるニオソーム形成性と その分散溶液の物理化学的性質を中心として一

堀 内照夫*1 . 田嶋 和夫苂

*1 ライオン(株) 物質科学センター（テ132-0035 東京都江戸川区平井 7-13-12）

*2 神奈川大学 工学部 化学教室（†221-8686 神奈川県横浜市神奈川区六角橋 27-1）

界面活性剤水溶液の分子集合状態，モデル膜の性質，ベシクルの調製法，ベシクル形成界面活性剤について述 ベた。べシクル形成界面活性剤の中でも, 非イオン界面活性剤は synthetic tailor-made lipid として注目されてい る。これはイオン性ベシクル形成剤に比較して生理的安全性が高く，かつ機能性付与のための分子設計が比較的 容易に行えるためである。筆者らは非イオン性両親媒性化合物の中でベシクル形成剂について探索した結果, ポ リ（オキシエチレン）硬化ひまし油にベシクル形成性を見出した。

本報告ではポリ（オキシエチレン）硬化ひまし油非イオン界面活性剤のベシクル系形成性とその分散液の物理 化学的性質について報告する。

（連絡者：堀内照夫） Vol.49, No.10,1107（2000） 